\title{
Auditor's Perception of Usage and Importance of Audit Technology in Vietnam
}

\author{
Binh Ngo Pham ${ }^{1}$, Thi Que Nguyen ${ }^{2}$, Manh Dung $\operatorname{Tran}^{3} \&$ Thi Thanh Phuong Nguyen ${ }^{4}$ \\ ${ }^{1}$ Logistics Department of Air Defense and Air Force, Vietnam \\ ${ }^{2}$ Hanoi University of Industry, Vietnam \\ ${ }^{3}$ National Economics University, Vietnam \\ ${ }^{4}$ Thuongmai University, Vietnam \\ Correspondence: Manh Dung Tran, Associate Professor, National Economics University, Vietnam.
}

Received: October 1, 2018

Accepted: October 19, $2018 \quad$ Online Published: November 28, 2018

doi:10.20849/abr.v3i3.513

URL: https://doi.org/10.20849/abr.v3i3.513

\begin{abstract}
This study is conducted for providing new evidence on the extent to which auditors are aware of the use and importance of audit technology in an age of industrial revolution 4.0. By using interviews and questionnaires of auditors at independent audit firms in the context of Vietnam, the findings show the high importance of using audit technology in technical and administrative procedures, particularly for risk assessment. We also assure the use and importance of audit technology is highly valued. The results help policymakers have guidance on the opportunities and challenges of using information technology in the audit process in independent audit.
\end{abstract}

Keywords: audit technology, audit software, information technology, Vietnam

\section{Introduction}

Information technology (IT) has been widespread in the global business environment for decades, especially with the rapid changes in customer demand and the desire to deal with competitors. Compete in providing a timely, better quality service at a lower cost. As a labor-intensive industry, audits require consistent consistency and efficiency to increase the auditor's productivity throughout the audit process. Therefore, the use of information technology in the audit process should enhance productivity, provide faster communication, and ensure the protection of customer data. In particular, recent auditing tendencies have put in place rules that put more pressure on auditing firms to become more efficient and willing to compete on price. So the topic of audit technology in aspects of perceptions and importance is much interested not only by auditors but also by stakeholders.

The purpose of this study is to examine the auditor's perception of the use and importance of audit technology in the Vietnamese audit market, with an emphasis on independent auditors and internal auditors as well. Specifically, the study set out some objective as (i) evaluate the use of knowledge and the importance of audit technology by auditors, auditors at independent audit firms in Vietnam; (ii) explore the types of audit technology tools used in the audit process; (iii) determine determinants influencing the use of audit technology in the auditing process; and (iv) investigate whether the use of audit technology in auditing procedures is relevant to the characteristics of audit firm. Although our study considers the use of information technology by independent audit firms doing business in the context of Vietnam.

\section{Literature Review}

Globalization in the 1990s has led to the emergence of an important social trend: the transition from industrial society to the knowledge society in which information plays a critical role. The development and application of information technology (IT) today signal a new era with great social change. Information technology has appeared in Vietnam since quite early, it can be said that it appears almost at the same time with the appearance of IT in the world. It is a comprehensive branch with many small branches such as telecommunication network, multimedia, internet, we can assert that in Vietnam a synchronized infrastructure has been built, complete in the information technology system. 
The introduction and expansion of technology to achieve more efficient production (Clarke, 1988). In the 1980s, the price of personal computers dropped dramatically to reach more people. Business environment has been characterized by the use of IT in enhancing business management and supporting decision making regulations.

According to Vietnam Association of Certified Public Accountants (VACPA), over the past 25 years, there have been only two independent auditing firms in the past 25 years. Certificate of qualification for auditing services, with nearly 11,000 employees working at audit firms across the country.

The use of IT in the audit, which we refer to throughout the research process, is an audit technology that plays an important role in enhancing the auditor's ability to audit. (Elliott and Jacobson 1987) outlines that audit technology refers to the tools that empower an individual to perform auditing tasks. Accordingly to Janvrin et al. (2008), they proposed that auditing technologies include audit applications, productivity tools, document review technology, and IT professionals. They view the use of audit technology as the level at which auditors use IT in each audit task, while the critical view of audit technology is the level of auditors significant. Associated with the use of IT in the audit.

Audit technology in history is called automation. It includes the use of computers in processes for complete planning, implementation and auditing to ensure consistent audit quality (Manson el al., 1998). However, higher quality audit is not the only motive for auditing firms to use IT in the audit process. Auditing standards encourage auditors to apply IT auditing tools and auditors (CAATs) in the auditing process, for example: fraud risk assessment; Identify articles and other adjustments to be checked; inventory assessment and adequacy; select sample transactions from key files; arranging transactions with specific characteristics; examine the whole population instead of sampling; have evidence of effective control; check the accuracy of electronic files; and repeat the procedure as Receivables Aging (AICPA, 2006; 2002a, 2002b, 2002c).

Previous research has attempted to develop models to explain and predict the success of the introduction and use of new technologies. For example, the Unified Theory of Acceptance and Use of Technology (UTAUT), developed by Venkatesh et al. (2003), was modified by Bierstaker et al. (2014) with audit background. They propose four key determinants that affect the adoption of technology: (i) user expectations about system performance; (ii) user awareness of the effort required to use the new system; (iii) user perceptions of the role of influencers in promoting system use; and (iv) user expectations about the existence of an appropriate infrastructure to support the use of the system. Previous evidence suggests that technology cannot improve performance unless it is used (eg. Venkatesh et al., 2003).

According to Ismail and Abidin (2009), the level of IT knowledge among auditors is lower than their perception of the importance of audit technology. Therefore, we investigate the use and importance of audit technology in the technical and administrative procedures of the auditing process, as perceived by auditor accountant.

According to Janvrin et al. (2008) and Bierstaker et al. (2014), the complexity of the customer's IT system influences the nature of the test check form chosen. In the context of complexity, where auditors rely on control, auditors are more likely to use IT in auditing procedures.

According to Janvrin et al. (2008), the use of audit technology in audit procedures varies by firm size. Sundgren and Svanström (2010) argue that audit quality is relatively lower in non-Big 4 firms. This is mainly because the auditor depends on fees from a single important customer and negatively affects the quality of the audit (Craswell et al., 2002). Differences in the quality of audits by firm size compared with the conclusion that Big 4's big firms may suffer reputational losses due to their investment in technology and capital. Ismail and Abidin (2009) found that the auditors of the four major Malaysian firms rated their overall IT knowledge better than the auditors of non-Big 4 firms.

Venkatesh et al. (2003) investigated the behavior of young and elderly workers using a new software system and concluded that this age affects the use of technology. Cleveland and Shore (1992) show that older workers are less engaged in vocational training than younger workers. Hartono (2012) concluded that IT knowledge of employees, at the management level associated with the firm's decision to apply public. Porter and Donthu (2006) found that the ease of use of the technology was found to be lower for the less educated. Previous evidence shows that less educated users have greater computer anxiety, hindering their ability to learn.

Porter and Donthu (2006) find that the perceived ease of technology use is lower for individuals who are less educated. Prior evidence suggests that less-educated users have greater computer anxiety, which forms an impediment to their learning ability (Hilgard \& Bower, 1975). furthermore, Agarwal and Prasad (1999) find a

significant positive association between education level and perceived ease of technology use. Moreover, Shih (2004) concludes that managerial control is a significant factor determining the use of technology in an 
organizational setting. Furthermore, Lee et al. (2006) argue that managerial support is positively associated with technology acceptance. Young and Jordan (2008) attribute this result to managerial influence on the implementation and use of new technologies. Similarly, Gambatese and Hallowell (2011) conclude that effective managerial support enables innovation implementation.

Abou-El-Sood et al. (2015) initiated and used qualitative and quantitative research to develop and validate a measurement technology scale including the following: firm/auditor against perception using audit technology in technical audit procedures; auditing characteristics compared to determinants influencing the use of audit technology in the auditing process; consequences of using audit technology during the audit process.

\section{Research Methodology}

The questionnaire consists of ten questions, divided into five sections, to assess the audiences' unawareness of the following aspects: (i) use of IT and its importance in audit procedures; (ii) use IT and its importance in administrative procedures; (iii) reasons for using audit technology in the auditing process; (iv) limiting the use of audit technology; and (v) the type of technology audit tool used in the audit process. This is followed by a section on the respondent's demographic data. Most of the answers were measured by a five-point Likert scale of 1 to 5 , with 1 indicating "little effect", and 5 indicating "very significant". By using SPSS software to produce results.

\subsection{Data Collection and Research Model}

When developing the investigation, we sent questionnaires to the auditors and assistant auditors at independent audit firms in Vietnam by distributing 40 questionnaires to each audit firm. We track respondents through the google docs. The result was 126 respondents.

To examine whether the use of perceived audit technology is relevant to the characteristics of the firm / auditor, we used the model as follows:

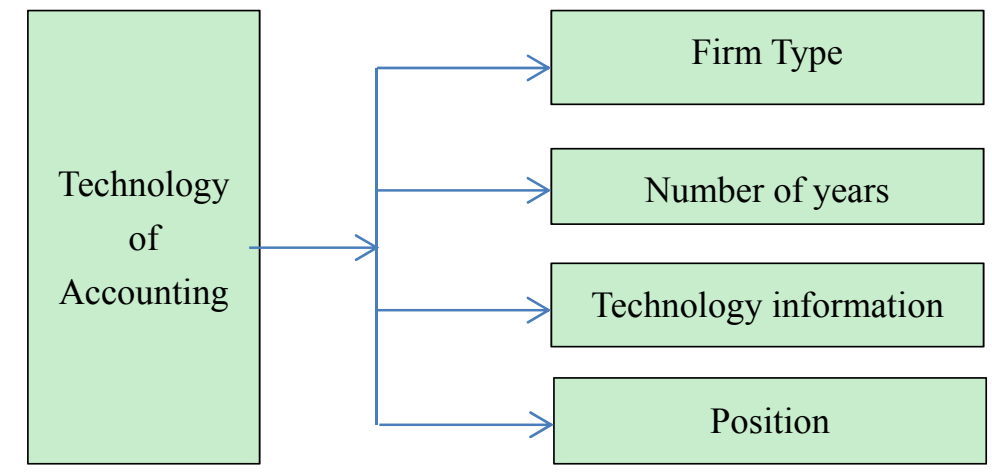

Figure 1. Research model

In particular, the auditing firm convention is equal to 1 if the audit firm is a Big 4 firm and equals 0 other firms; Years of experience: 1 if the experience is 5 years or more, 0 if less than 5 years. IT qualifications: 1 for university and postgraduate, 0 for undergraduate. Function: 1 if the auditor and the auditor, 0 assistant auditors and other.

Audit technology: Characteristics of the firm/auditor against the perception of the use of audit technology in technical audit procedures; Auditing characteristics compared to determinants affecting the use of audit technology in the auditing process; Consequences of using audit technology during the audit process.

\section{Results and Discussions}

This section begins with a presentation of preliminary results and descriptions. We then discussed the results of the auditor's perception of the use and importance of audit technology in auditing procedures. The final section provides the result of the connection between the use of the perception of the audit technology in the audit procedures and the characteristics of the firm / auditor. By using SPSS 22, we have the following results:

\subsection{Preliminary Analysis and Descriptive Statistics}

Table 1 shows that $24.6 \%$ of the respondents were experienced auditors with 10 years of experience at various levels, from auditors to partners, $52 \%$ experienced less than 5 years, $5-10$ years accounted for $34.1 \%$. 
Table 1. Years of work experiences

\begin{tabular}{llcccc}
\hline & Frequency & Percent & Valid Percent & Cumulative Percent \\
\hline Valid & $<5$ years & 52 & 41.3 & 41.3 & 41.3 \\
& $>$ 10 years & 31 & 24.6 & 24.6 & 65.9 \\
& From 5 to 10 years & 43 & 34.1 & 34.1 & 100.0 \\
& Total & 126 & 100.0 & 100.0 & \\
\hline
\end{tabular}

About the type of firm, Table 2 shows that about 31\% work in Big 4 audit firms and $69 \%$ work in other audit firms.

Table 2. Types of audit firms

\begin{tabular}{llcccc}
\hline & & Frequency & Percent & Valid Percent & Cumulative Percent \\
\hline Valid & Big 4 & 39 & 31.0 & 31.0 & 31.0 \\
& Others & 87 & 69.0 & 69.0 & 100.0 \\
& Total & 126 & 100.0 & 100.0 & \\
\hline
\end{tabular}

To review the IT expertise of the auditors in the auditing firm, survey results show that: Table 3: Level of information.

Table 3. Type of audit firm - IT expertise cross tabulation

\begin{tabular}{llllccc}
\hline & & \multicolumn{4}{c}{ IT Expertise } & \multirow{2}{*}{ Total } \\
\cline { 3 - 6 } & & College & University & After university & Intermediate & Tota \\
\hline Type of audit firm & Big 4 & 8 & 26 & - & 59 & 87 \\
& Others & 16 & 45 & 4 & 22 & 126 \\
\hline \multirow{2}{*}{ Total } & & 24 & 71 & 4 & 27 & 126 \\
\hline
\end{tabular}

The types of auditing tools used in the auditing process, see Table 4, almost auditing firms in the big 4 group use custom designed audit software, While other audit firms used Microsoft Office for auditing purposes, the majority ( 87 of the 87 respondents, 58 reported using Microsoft Office for audit).

Table 4. Type of audit firm - Audit software usage

\begin{tabular}{lccccc}
\hline & & \multicolumn{3}{c}{ The audit software usage } & \\
\cline { 3 - 5 } & & Others & $\begin{array}{c}\text { Microsoft } \\
\text { Office }\end{array}$ & $\begin{array}{c}\text { Audit software } \\
\text { self-design }\end{array}$ & Total \\
\hline \multirow{2}{*}{ Type of audit firms } & Big 4 & - & 6 & 33 & 39 \\
& Others & 18 & 58 & 11 & 87 \\
Total & 18 & 64 & 44 & 126 \\
\hline
\end{tabular}

Looking at Table 5, we find that the number of years of auditing experience over 5 years in Big 4 audit firms is high (39 out of 39 respondents have experienced over 5 years). The number of years of auditing experience in other audit firms is quite young (less than 5 years). 
Table 5. Type of audit firms - Years of working experiences

\begin{tabular}{llcccc}
\hline & & \multicolumn{3}{c}{ Years of professional experiences } & \\
\cline { 3 - 5 } & & $\mathbf{5}$ years & $>\mathbf{1 0}$ years & $\begin{array}{c}\text { From 5 to 10 } \\
\text { years }\end{array}$ & Total \\
\hline \multirow{2}{*}{ Type of audit firms } & Big 4 & 11 & 11 & 17 & 39 \\
& Others & 41 & 20 & 26 & 87 \\
Total & 52 & 31 & 43 & 126 \\
\hline
\end{tabular}

Looking at Table 6 we find that almost all audit firms use the audit firm infrastructure: Wireless network.

Table 6. Type of audit firms - Infrastructure usage

\begin{tabular}{llcccc}
\hline & & \multicolumn{3}{c}{ The infrastructure usage } & \\
\cline { 3 - 5 } & & Others & $\begin{array}{c}\text { Network access } \\
\text { from remote }\end{array}$ & $\begin{array}{c}\text { Wireless } \\
\text { network }\end{array}$ & Total \\
\hline Type of audit firms & Big 4 & - & 12 & 27 & 39 \\
& Others & 11 & 12 & 64 & 87 \\
Total & 11 & 24 & 91 & 126 \\
\hline
\end{tabular}

Inspection of technology in technical and administrative procedures, look at Table 7 we have some following data:

Table 7. Audit and administrative procedures $(\mathrm{n}=126)$

\begin{tabular}{lrrrrrrr}
\hline \multicolumn{1}{c}{ Items } & $\mathbf{n}$ & $\mathbf{1}$ & $\mathbf{2}$ & $\mathbf{3}$ & $\mathbf{4}$ & $\mathbf{5}$ & Mean \\
\hline I. Audit procedures & & & & & & & \\
Accept customers & 126 & 12.7 & 42.9 & 6.3 & 26.2 & 11.9 & 2.817 \\
Preparation of audits & 126 & 11.1 & 15.9 & 14.3 & 41.3 & 17.5 & 3.381 \\
Audit planning & 126 & 7.9 & 13.5 & 14.3 & 41.3 & 23 & 3.579 \\
Preparation of audit programs & 126 & 7.9 & 13.5 & 11.1 & 38.9 & 28.6 & 3.667 \\
Check compliance with accounting standards and & 126 & 6.3 & 18.3 & 15.1 & 37.3 & 23 & 3.524 \\
auditing & & & & & & & \\
Internal control rating & 126 & 7.9 & 13.5 & 12.7 & 40.5 & 25.4 & 3.619 \\
Risk assessment & 126 & 6.3 & 18.3 & 7.1 & 42.9 & 25.4 & 3.627 \\
Sample & 126 & 7.9 & 10.3 & 12.7 & 40.6 & 28.6 & 3.712 \\
Fraud evaluation & 126 & 4 & 18.3 & 9.5 & 43.7 & 24.6 & 3.656 \\
Evaluation of audit evidence & 126 & 9.5 & 18.3 & 7.1 & 42.9 & 22.2 & 3.5 \\
Calculate, physical examination & 126 & 14.3 & 19.8 & 7.9 & 34.9 & 23 & 3.325 \\
Analytical review & 126 & 11.1 & 9.5 & 11.9 & 44.4 & 23 & 3.587 \\
Check the details & 126 & 6.3 & 23 & 11.1 & 31 & 28.6 & 3.512 \\
Write a report & 126 & 5.6 & 11.1 & 8.7 & 48.4 & 26.2 & 3.786 \\
II. Administrative procedures related to auditing & & & & & & & \\
Get to know the customer & 126 & 22.2 & 27 & 7.9 & 35.7 & 7.1 & 2.786 \\
Schedule time and cost budgeting & 126 & 11.9 & 34.9 & 7.9 & 35.7 & 9.5 & 2.960 \\
Time / cost calculation & 126 & 12.7 & 20.6 & 11.9 & 46 & 8.7 & 3.175
\end{tabular}


Assignment of audit team tasks

Record and monitor the costs incurred for the audit

Commit to the independence of the audit team

Review the factors that affect independence and protection

Time recording and track rotation KTV in charge

Discuss with the unit director about the audit plan

Maintain / update the file permanently

Issue invoice to customer

$\begin{array}{rrrrrrr}126 & 5.6 & 21.4 & 12.7 & 40.5 & 19.8 & 3.476 \\ 126 & 2.4 & 28.6 & 12.7 & 33.3 & 23 & 3.460 \\ 126 & 4.8 & 25.4 & 12.7 & 34.1 & 23 & 3.452 \\ 126 & 11.9 & 24.6 & 5.6 & 36.5 & 21.4 & 3.310 \\ 126 & 5.6 & 25.4 & 13.5 & 38.9 & 16.7 & 3.357 \\ 126 & 5.6 & 21.4 & 11.9 & 42.9 & 18.3 & 3.468 \\ 126 & 4.8 & 28.6 & 9.5 & 31 & 26.2 & 3.452 \\ 126 & 8.7 & 23.8 & 15.1 & 33.3 & 19 & 3.302\end{array}$

In which: (1): Very little influence (\%); (2) Little influence (\%); (3): Neutral (\%); (4) Influence (\%); (5): Big influence $(\%)$.

The results in Part I of Table 7 show that technology audits are widely used in technical auditing procedures, reflected by means for the evaluation elements. From the 14 audit procedures listed in the questionnaire, Writing the report is the most commonly used audit technology (according to the number of responses to the 'used method'), then sampling. Respondents highly valued the importance of using accounting technology in technical audit procedures. The use of audit technology in risk assessment was assessed as significant with an average of 3.627. Sampling is secondary to importance with an average of 3.712 .

Interestingly, respondents said that fraudulent assessment is a factor that audit technology is quite important. However, it is not used appropriately, as disclosed by the corresponding rate of use compared to the importance of audit technology is $43.7 \%$ and $24.6 \%$. Similarly, evaluating audit evidence is understood as a factor in the importance of audit technology over its actual value $(65.1 \%$ of respondents believe that information technology has an impact. This compares to only $9.5 \%$ of respondents saying that it is actually used but less).

Part II of Table 7 presents findings on the perception of use and importance of audit technology in administrative auditing procedures. Assignment of audit team tasks is categorized as administrative procedures when the accounting technology is most commonly used, followed by an exchange with the unit management of the audit plan. For the auditor's perception of the importance of audit technology in administrative procedures, the use of audit technology in assigning audit team tasks is most influential with an average of 3.476.

The perception of the questioner about the importance of audit technology does not necessarily indicate its widespread use in related administrative procedures to audit. Calculating the time to change from the budget is one factor that the assessment technology is very important because of 46 percent of the respondents.

Table 8. Reasons for usage of audit technology in an audit

\begin{tabular}{lllllll}
\hline Items & $\mathbf{1}$ & $\mathbf{2}$ & $\mathbf{3}$ & $\mathbf{4}$ & $\mathbf{5}$ & Mean \\
\hline To improve the quality of the audit & 11.9 & 25.4 & 7.1 & 40.5 & 15.1 & 3.214 \\
To minimize the time and cost of audit tasks & 4 & 9.5 & 6.3 & 56.3 & 23.8 & 3.865 \\
To survive in an IT-based audit environment & 4 & 10.3 & 9.5 & 54.8 & 21.4 & 3.794 \\
To gain competitive advantage over other firms & 4.8 & 16.7 & 6.3 & 38.9 & 33.3 & 3.794 \\
To allows auditor to operate anywhere & 5.6 & 23 & 11.1 & 38.1 & 22.2 & 3.484 \\
To better manage the audit process & 4 & 15.9 & 8.7 & 53.2 & 18.3 & 3.659 \\
To unite globally & 7.9 & 16.7 & 10.3 & 43.7 & 21.4 & 3.540 \\
To meet the expectations of customers & 7.1 & 19 & 4.8 & 43.7 & 25.4 & 3.611 \\
To minimize the risk of auditing & 7.1 & 10.3 & 12.7 & 40.5 & 29.4 & 3.746 \\
To simplify the audit process & 3.2 & 15.1 & 6.3 & 42.9 & 32.5 & 3.865 \\
To pay more attention to risk areas & 3.2 & 14.3 & 9.5 & 42.1 & 31 & 3.833 \\
\hline
\end{tabular}


As shown in Table 8, the majority of respondents said that the most important reason for using audit technology during the audit process is to improve audit quality and minimize the time and expense of auditing tasks and to simplify the process, while other respondents find that the most important reason for the use of audit technology is to minimize the time and cost of auditing tasks, to simplify the audit process and pay more attention to risk areas (i.e. 3.865 and 3.833).

Table 9. Limitations of usage of audit technique from auditors

\begin{tabular}{lrrrrrr}
\hline \multicolumn{1}{c}{ Items } & $\mathbf{1}$ & $\mathbf{2}$ & $\mathbf{3}$ & $\mathbf{4}$ & $\mathbf{5}$ & Mean \\
\hline Lack of IT audit training & 26.2 & 31 & 9.5 & 20.6 & 12.7 & 2.627 \\
Lack of knowledge / expertise on IT by auditors & 8.7 & 34.9 & 6.3 & 36.5 & 13.5 & 3.111 \\
Difficulty in applying software in real situations & 5.6 & 21.4 & 17.5 & 32.5 & 23 & 3.460 \\
The risk of losing sensitive information is stored in the & 7.9 & 23 & 11.9 & 35.7 & 21.4 & 3.397 \\
computer & & & & & & \\
Difficult to quantify the benefits and costs of IT & 6.3 & 15.9 & 12.7 & 41.3 & 23.8 & 3.603 \\
Lack of enthusiasm for IT in senior auditors & 4 & 19 & 14.3 & 46 & 16.7 & 3.524 \\
\hline
\end{tabular}

On the other hand, Table 9 shows that the difficulty in quantifying the benefits and costs of information technology and the lack of enthusiasm for information technology in high-level auditors are believed to have a great impact on the use Information technology in the audit (average level (3,603 and 3,524). Meanwhile, the lack of training in IT audit does not affect the audit process (mean $=2.627$ ).

In general, the respondents emphasized higher quality and higher efficiency than those related to the use of audit technology. The main difficulty, however, is the lack of IT training and lack of enthusiasm for information technology in auditing and the difficulty of applying software in real-world situations. Therefore, firms apply the required audit technology to have intensive training programs and focus on corporate culture. A related literature-based interpretation of cultural integration.

Table 10. Results of usage increase of audit technique

\begin{tabular}{lrrrrrr}
\hline \multicolumn{1}{c}{ Items } & $\mathbf{1}$ & $\mathbf{2}$ & $\mathbf{3}$ & $\mathbf{4}$ & $\mathbf{5}$ & Mean \\
\hline $\begin{array}{l}\text { The assessment of the partner / manager's work was done } \\
\text { in a timely manner }\end{array}$ & 7.9 & 19 & 12.7 & 50.8 & 9.5 & 3.349 \\
$\begin{array}{l}\text { Experienced staff has more time to focus on high risk } \\
\text { areas }\end{array}$ & 3.2 & 15.1 & 9.5 & 42.9 & 29.4 & 3.802 \\
$\begin{array}{l}\text { The assessment of partner / manager work has been made } \\
\text { easier }\end{array}$ & 1.6 & 21.4 & 6.3 & 50 & 20.6 & 3.667 \\
Emphasis is put on recruiting audits with IT skills & 2.4 & 21.4 & 9.5 & 47.6 & 19 & 3.595 \\
Many audit tasks have been simplified & 4.8 & 12.7 & 12.7 & 44.4 & 25.4 & 3.730 \\
Job satisfaction of auditors increased & 4 & 15.1 & 7.9 & 42.9 & 30.2 & 3.802 \\
Other IT professionals recruited by audit firms & 2.4 & 12.7 & 13.5 & 43.7 & 27.8 & 3.817 \\
IT auditors hold higher positions in audit firms & 3.2 & 11.1 & 15.9 & 33.3 & 36.5 & 3.889 \\
\hline
\end{tabular}

Looking at Table 10, we find that auditors are aware of the importance of information technology in auditing, leading IT auditors to hold higher-level positions in auditing firms. The higher the clutch $($ mean $=3,889)$. Besides that, Other comments also found that the application of information technology to the audit of experienced staff has a lot of time to focus on high-risk areas, while increasing the satisfaction of auditors increased $($ mean $=3.802)$. 
Table 11. Characteristics of audit firms vs. perceptions of audit technology usage

\begin{tabular}{|c|c|c|c|c|c|}
\hline Variables & $\begin{array}{c}\text { Audit firm } \\
\text { type }\end{array}$ & $\begin{array}{l}\text { No. years of } \\
\text { experiences }\end{array}$ & IT level & Position & $\mathbf{R}^{2}$ \\
\hline Accept customers & $\begin{array}{l}1.108 \\
(0.27)\end{array}$ & $\begin{array}{l}-0.309 \\
(0.75)\end{array}$ & $\begin{array}{c}-3.536 \\
(<0.01 * * *)\end{array}$ & $\begin{array}{c}-2.554 \\
(<0.01 * * *)\end{array}$ & 0.102 \\
\hline Preparation of audits & $\begin{array}{c}1.175 \\
(0.242)\end{array}$ & $\begin{array}{l}-0.259 \\
(0.796)\end{array}$ & $\begin{array}{c}-3.134 \\
(<0.05 * *)\end{array}$ & $\begin{array}{l}-1.514 \\
\left(<0.1^{*}\right)\end{array}$ & 0.57 \\
\hline Audit planning & $\begin{array}{c}0.884 \\
\left(<0.05^{* *}\right)\end{array}$ & $\begin{array}{c}1.912 \\
\left(<0.05^{* *}\right)\end{array}$ & $\begin{array}{l}-0.643 \\
(0.521)\end{array}$ & $\begin{array}{l}-1.549 \\
\left(<0.1^{*}\right)\end{array}$ & 0.23 \\
\hline Preparation of audit programs & $\begin{array}{c}2.252 \\
\left(<0.05^{* *}\right)\end{array}$ & $\begin{array}{c}3.427 \\
(<0.01 * * *)\end{array}$ & $\begin{array}{c}-2.689 \\
(<0.05 * *)\end{array}$ & $\begin{array}{l}-1.509 \\
(0.134)\end{array}$ & 0.139 \\
\hline $\begin{array}{l}\text { Check compliance with accounting } \\
\text { standards and auditing }\end{array}$ & $\begin{array}{c}2.395 \\
\left(<0.05^{* *}\right)\end{array}$ & $\begin{array}{c}2.342 \\
(<0.05 * *)\end{array}$ & $\begin{array}{c}2.259 \\
\left(<0.05^{* *}\right)\end{array}$ & $\begin{array}{c}-2.217 \\
(<0.05 * *)\end{array}$ & 0.583 \\
\hline Internal control rating & $\begin{array}{c}0.931 \\
(0.354)\end{array}$ & $\begin{array}{c}1.058 \\
(0.292)\end{array}$ & $\begin{array}{l}-1.615 \\
(<0.1 *)\end{array}$ & $\begin{array}{l}-0.862 \\
(0.39)\end{array}$ & 0.105 \\
\hline Risk assessment & $\begin{array}{c}0.149 \\
(0.882)\end{array}$ & $\begin{array}{c}2.019 \\
\left(<0.05^{* *}\right)\end{array}$ & $\begin{array}{l}-1.493 \\
\left(<0.1^{*}\right)\end{array}$ & $\begin{array}{c}-1.721 \\
\left(<0.05^{* *}\right)\end{array}$ & 0.26 \\
\hline Sample & $\begin{array}{c}0.379 \\
(0.705)\end{array}$ & $\begin{array}{c}3.114 \\
\left(<0.05^{* *}\right)\end{array}$ & $\begin{array}{c}-2.358 \\
\left(<0.05^{* *}\right)\end{array}$ & $\begin{array}{c}-2.850 \\
\left(<0.05^{* *}\right)\end{array}$ & 0.36 \\
\hline Fraud evaluation & $\begin{array}{c}4.171 \\
(<0.1 *)\end{array}$ & $\begin{array}{c}1.679 \\
\left(<0.1^{*}\right)\end{array}$ & $\begin{array}{c}-2.295 \\
(<0.05 * *)\end{array}$ & $\begin{array}{l}-1.671 \\
\left(<0.1^{*}\right)\end{array}$ & 0.453 \\
\hline Evaluation of audit evidence & $\begin{array}{c}0.530 \\
(0.597)\end{array}$ & $\begin{array}{c}0.627 \\
(0.532)\end{array}$ & $\begin{array}{c}1.541 \\
(0.126)\end{array}$ & $\begin{array}{l}-1.111 \\
(0.269)\end{array}$ & 0.03 \\
\hline Calculate, physical examination & $\begin{array}{c}1.274 \\
(0.205)\end{array}$ & $\begin{array}{c}-0.03 \\
(0.998)\end{array}$ & $\begin{array}{l}-0.649 \\
(0.517)\end{array}$ & $\begin{array}{l}-1.381 \\
(0.17)\end{array}$ & 0.024 \\
\hline Analytical review & $\begin{array}{c}-0.664 \\
\left(<0.05^{* *}\right)\end{array}$ & $\begin{array}{c}2.616 \\
(<0.01 * * *)\end{array}$ & $\begin{array}{c}-1.10 \\
(0.274)\end{array}$ & $\begin{array}{c}-2.362 \\
\left(<0.05^{* *}\right)\end{array}$ & 0.297 \\
\hline Check the details & $\begin{array}{c}1.587 \\
\left(<0.1^{*}\right)\end{array}$ & $\begin{array}{l}-0.209 \\
(0.835)\end{array}$ & $\begin{array}{l}-1.311 \\
(0.192)\end{array}$ & $\begin{array}{c}-2.117 \\
\left(<0.05^{* *}\right)\end{array}$ & 0.23 \\
\hline Write a report & $\begin{array}{c}1.306 \\
\left(<0.1^{*}\right)\end{array}$ & $\begin{array}{c}2.896 \\
(<0.01 * * *)\end{array}$ & $\begin{array}{l}-1.551 \\
\left(<0.1^{*}\right)\end{array}$ & $\begin{array}{c}-2.588 \\
(<0.01 * * *)\end{array}$ & 0.32 \\
\hline
\end{tabular}

Note: $* * *$ and $* * *$ express the meaning at $10 \%, 5 \%$ and $1 \%$ respectively

The results in Table 11 illustrate the connection between the perception of the use of audit technology in auditing procedures and the characteristics of the firm/auditor. The coefficients of interceptions are not reported.

The type of auditing firm involved in the use of audit technology, however, some audit procedures are not statistically significant such as customer acceptance, audit preparation, internal audit evaluation, risk assessment, sampling, audit evidence, physical examination (P-values of 0.27, 0.242, 0.354, 0.882, 0.705, 0.597; 0.205 respectively).

As we have speculated, the number of years of experience is related to the use of audit technology in auditing procedures. Therefore, many years of experience auditors are in the firm, they are less likely to be aware of the use of audit technology to be in the audit procedures. Achieved results are conventional for most audit procedures. For audit procedures to accept customers, prepare audits, internal control assessment, audit evidence evaluation, material examination calculations, detailed test results are not significant at 0.1 ( $\mathrm{p}$-values are 0.75 , $0.796,0.992,0.532,0.998$, and 0.835 respectively). Whereby, workers have little business more knowledge of 
technology is useful in enhancing their work Improve productivity and productivity. Therefore, technology can be considered a competitive industry to advance their career advancement.

For IT qualifications, the results show that the level of IT expertise of active auditors is closely linked to the use of audit techniques in auditing procedures. Users with more expertise have overcome any technological worries.

Information and focus on the usefulness of technology, while those who use less information technology are interested in using IT easily. However, the IT level of the auditor does not affect audit procedures: auditing, calculating, material inspection, analysis and detailed examination (p-values: 0.532, 0.998, and 0.835).

As far as positions are concerned, we find that the position influences the use of information technology in the audit technique. The higher the position, the more information technology is required.

The coefficients of most audit procedures are significant at the normal level. An explanation of the negligible results for some audit procedures is that the respondent is considered Lack of knowledge / expertise in IT auditors as one of the primary obstacles to the use of audit technology. Overall, our results confirm our expectation.

Table 12. Characteristics of audit firms vs. determinants impacting audit technology

\begin{tabular}{|c|c|c|c|c|c|}
\hline Attributes & $\begin{array}{c}\text { Audit firm } \\
\text { type }\end{array}$ & $\begin{array}{l}\text { No. years of } \\
\text { experiences }\end{array}$ & IT level & Position & $\mathbf{R}^{2}$ \\
\hline To improve the quality of the audit & $\begin{array}{l}-0.196 \\
(0.845)\end{array}$ & $\begin{array}{c}2.455 \\
(<0.01 * * *)\end{array}$ & $\begin{array}{c}1.138 \\
\left(<0.1^{*}\right)\end{array}$ & $\begin{array}{c}-2.492 \\
(<0.01 * * *)\end{array}$ & 0.289 \\
\hline $\begin{array}{l}\text { To minimize the time and cost of audit } \\
\text { tasks }\end{array}$ & $\begin{array}{c}2.021 \\
\left(<0.05^{* *}\right)\end{array}$ & $\begin{array}{c}1.353 \\
\left(<0.1^{*}\right)\end{array}$ & $\begin{array}{l}-1.673 \\
\left(<0.1^{*}\right)\end{array}$ & $\begin{array}{l}-1.119 \\
(0.246)\end{array}$ & 0.25 \\
\hline $\begin{array}{l}\text { To survive in an IT-based audit } \\
\text { environment }\end{array}$ & $\begin{array}{l}-0.115 \\
(0.908)\end{array}$ & $\begin{array}{c}3.114 \\
\left(<0.05^{* *}\right)\end{array}$ & $\begin{array}{c}1.955 \\
\left(<0.05^{* *}\right)\end{array}$ & $\begin{array}{l}-1.487 \\
(<0.1 *)\end{array}$ & 0.32 \\
\hline $\begin{array}{l}\text { To gain competitive advantage over } \\
\text { other firms }\end{array}$ & $\begin{array}{c}0.799 \\
(0.426)\end{array}$ & $\begin{array}{c}1.271 \\
(0.206)\end{array}$ & $\begin{array}{l}-0.853 \\
(0.395)\end{array}$ & $\begin{array}{l}-1.7656 \\
\left(<0.1^{*}\right)\end{array}$ & 0.182 \\
\hline Allows auditors to operate anywhere & $\begin{array}{c}-0.53 \\
(0.958)\end{array}$ & $\begin{array}{c}1.299 \\
(0.196)\end{array}$ & $\begin{array}{c}0.52 \\
(0.604)\end{array}$ & $\begin{array}{c}0.586 \\
(0.559)\end{array}$ & 0.027 \\
\hline To better manage the audit process & $\begin{array}{c}2.275 \\
(<0.01 *)\end{array}$ & $\begin{array}{c}1.115 \\
(0.252)\end{array}$ & $\begin{array}{c}0.15 \\
(0.988)\end{array}$ & $\begin{array}{c}-1951 \\
(<0.1 *)\end{array}$ & 0.275 \\
\hline To unite globally & $\begin{array}{c}1.957 \\
(<0.1 *)\end{array}$ & $\begin{array}{c}2.883 \\
(<0.01 * * *)\end{array}$ & $\begin{array}{c}0.073 \\
\left(<0.1^{*}\right)\end{array}$ & $\begin{array}{c}-0.06 \\
(0.544)\end{array}$ & 0.327 \\
\hline To meet the expectations of customers & $\begin{array}{c}1.605 \\
\left(<0.1^{*}\right)\end{array}$ & $\begin{array}{c}2.798 \\
(<0.01 * * *)\end{array}$ & $\begin{array}{c}0.083 \\
(0.934)\end{array}$ & $\begin{array}{c}-2.214 \\
(<0.05 * *)\end{array}$ & 0.296 \\
\hline To minimize the risk of auditing & $\begin{array}{c}0.813 \\
(0.418)\end{array}$ & $\begin{array}{c}0.711 \\
(0.479)\end{array}$ & $\begin{array}{c}-2.118 \\
\left(<0.05^{* *}\right)\end{array}$ & $\begin{array}{c}-2.318 \\
\left(<0.05^{* *}\right)\end{array}$ & 0.264 \\
\hline To simplify the audit process & $\begin{array}{c}2.484 \\
(<0.01 * * *)\end{array}$ & $\begin{array}{l}1.289 \\
(0.2)\end{array}$ & $\begin{array}{c}-2.029 \\
\left(<0.05^{* *}\right)\end{array}$ & $\begin{array}{c}-2.212 \\
(<0.05 * *)\end{array}$ & 0.298 \\
\hline Pay more attention to risk areas & $\begin{array}{c}1.406 \\
\left(<0.1^{*}\right)\end{array}$ & $\begin{array}{c}2.267 \\
\left(<0.05^{* *}\right)\end{array}$ & $\begin{array}{l}0.758 \\
(0.45)\end{array}$ & $\begin{array}{l}0.441 \\
(0.66)\end{array}$ & 0.302 \\
\hline
\end{tabular}

Note: $* * *$ and $* * *$ express the meaning at $10 \%, 5 \%$ and $1 \%$ respectively

Audit implementation is conducted by using audit technology has some consequences as below: 
Table 13. Consequences of audit technology usage in audit performance

\begin{tabular}{lccccc}
\hline \multicolumn{1}{c}{ Attributes } & $\begin{array}{c}\text { Audit firm } \\
\text { type }\end{array}$ & $\begin{array}{c}\text { No. years of } \\
\text { experiences }\end{array}$ & IT level & Position & $\mathbf{R}^{2}$ \\
\hline $\begin{array}{l}\text { The assessment of partner/manager's } \\
\text { work was done in a timely manner }\end{array}$ & -1.217 & 1.472 & 1.354 & -0.333 & 0.195 \\
Experienced staff has more time to & -0.331 & 3.183 & 1.508 & -0.440 & 0.306 \\
focus on high risk areas & $(0.741)$ & $\left(<0.01^{* * *}\right)$ & $\left(<0.1^{*}\right)$ & $(0.660)$ & \\
The assessment of partner / manager & 0.08 & 0.717 & -7.95 & -1.242 & 0.134 \\
work has been made easier & $(0.936)$ & $(0.475)$ & $(0.428)$ & $(0.217)$ & \\
Emphasis is put on recruiting audits & -1.343 & 2.252 & 0.061 & -2.240 & 0.287 \\
with IT skills & $\left(<0.1^{*}\right)$ & $\left(<0.05^{* *}\right)$ & $(0.952)$ & $\left(<0.05^{* *}\right)$ & \\
Many audit tasks have been simplified & 0.913 & 1.508 & -0.3 & -1.217 & 0.167 \\
& $(0.363)$ & $(0.134)$ & $(0.765)$ & $(0.226)$ & \\
Job satisfaction of auditors increased & 0.847 & 2.049 & -0.824 & -0.588 & 0.125 \\
Other IT professionals recruited by & $(0.398)$ & $\left(<0.05^{* *}\right)$ & $(0.412)$ & $(0.558)$ & \\
audit firms & 1.827 & 1.43 & -5.4 & -1.787 & 0.223 \\
IT auditors hold higher positions in & $\left(<0.1^{*}\right)$ & $\left(<0.1^{*}\right)$ & $(0.59)$ & $(<0.1 *)$ & \\
audit firms & 2.858 & 0.882 & -0.825 & -1.161 & 0.269 \\
\hline
\end{tabular}

Note: $* * *$ and $* * *$ express the meaning at $10 \%, 5 \%$ and $1 \%$ respectively

Looking at Table 12 shows the results of examining the relationship between cognitive reasoning using audit technology in the auditing process and demographic characteristics of the participants. Highly educated, postgraduate, and cognitive respondents improved audit quality, reduced audit time and costs, reduced audit risk, and simplified process Audit is the most important in the use of audit technology. On the other hand, when respondents have more years of experience, they perceive that the reasons are not relevant weight. This end result may be due to years of experience with relatively low levels of participation in IT training, by reducing confidence in their ability to learn (Cleveland and Shore, 1992). The respondents had a large number of ICT specialists considering all the significant reasons, while respondents at management level, supervisory level, or partner level thought that the most important reasons for using the test technology The math is to minimize the time and expense of task audit, to minimize audit risk, and to pay more attention to the risk area. In general, the global coefficients are consistent and satisfying customer expectations are negligible at levels usually, common, normal. However, the significance of the determinants increases with the level of IT expertise of the auditor.

Regarding the link between the cognitive consequences of using audit technology and the characteristics of the respondents, the results in Table 13 reveal that respondents have a graduate degree, With less experience, Knowledge of IT and management positions is recognized by the review of the work of the partners / managers and Emphasis on recruiting IT auditors is one of the most important consequences.

Overall, these findings are consistent with previous results that respondents with postgraduate education and IT expertise are more affected by perceptive ease of use.

\section{Conclusions and Recommendations}

Although auditing standards encourage the use of information technology in auditing, previous studies lacked the use of accounting technology in industrial revolution markets 4.0. The contribution of our article stems from its application to a revolutionary 4.0 technology environment, unlike previous studies that focused primarily on development markets. These results are particularly relevant for auditors, managers, and the academic community on improving the quality of audits by using audit technology.

Audit technology is widely used in both technical and administrative audits of Preparation of Working Documents and Sampling. Auditors generally consider audit technology to be most important in risk assessment and sampling. For the use and importance of audit technology in administrative auditing procedures, issue 
customer invoices and summarize the results to review the top-ranked list. The leading reason for using audit technology is that it is important to improve the quality of auditing. However, the lack of auditor training and Lack of knowledge/expertise in IT of auditors are considered as the main constraints to the use of audit technology. This reflects a general cultural trend that needs further investigation.

The determinants are most likely to explain why the nature and extent of interaction differ between the Big 4 and the non-Big 4 firms including their training facilities, expertise, and administrative support. Such determinants can affect the degree of cultural integration and reflect appropriately the adoption of IT in Vietnamese audit firms. To investigate the impact, if any, of such determinants, requires an interview-based survey to assess the extent of the cultural integration process and its potential impact on IT levels. And / or respondents' perceptions of the use of IT in the audit process.

Finally, regarding the relationship between the use of the recognized technology and the characteristics of the firm / auditor, our evidence suggests that the use of technology audits in auditing procedures The assessment is significant when the IT auditor level increases, and when the auditing firm is a large firm 4, while the use of audit technology in auditing procedures is reduced by the auditor's experience. More detailed analysis provides rich results on specific determinants that shape the perception of respondents about the importance of audit technology. This perception is significantly affected by the demographic characteristics of the auditor. These results have significant implications for the decision to apply audit technology in audit firms.

There are some limitations to this study. First, the main limitation of this study is the relatively small number of responses. Although respondents may be the ones who are most concerned about the issues being investigated and therefore, as can be said, are also the most informed, their views may not represent those people are not respondents. Second, the sample was not balanced because respondents from other audit firms were over represented by Big 4's big firms.

\section{References}

Abou-El-Sood, H., Kotb, A., \& Allam, A. (2015). Exploring auditors' perceptions of the usage and importance of audit information technology. International Journal of Auditing, 19(3), 252-266. https://doi.org/10.1111/ijau.12039

Agarwal, R., \& Prasad, J. (1999). Are individual differences germane to the acceptance of new information technologies?. Decision Sciences, 30(2), 361-391. https://doi.org/10.1111/j.1540-5915.1999.tb01614.x

AICPA. (2006). Risk assessment standards. Statement of Auditing Standards, No. 104-11. New York: American Institute of Certified Public Accountants.

AICPA. (2002a). Audit documentation. Statement of Auditing Standards. New York: American Institute of Certified Public Accountants.

AICPA. (2002b). Consideration of fraud in financial statement audit. Statement of Auditing Standards, No. 99. New York: American Institute of Certified Public Accountants.

AICPA. (2002c). Interim financial information. Statement of Auditing Standards, No. 100. New York: American Institute of Certified Public Accountants.

Bierstaker, J., Janvrin, D., \& Love, D. (2014). What factors influence auditors' use of computer-assisted audit techniques?. Advances in Accounting, 30(1), 67-74. https://doi.org/10.1016/j.adiac.2013.12.005

Clarke, R. (1988). Information technology and dataveillance. Communications of the ACM, 31(5), 498-512. https://doi.org/10.1145/42411.42413

Cleveland, J.N., \& Shore, L.M. (1992). Self-and supervisory perspectives on age and work attitudes and performance. Journal of applied Psychology, 77(4), 469. https://doi.org/10.1037/0021-9010.77.4.469

Craswell, A., Stokes, D.J., \& Laughton, J. (2002). Auditor independence and fee dependence. Journal of Accounting and Economics, 33(2), 253-275. https://doi.org/10.1016/S0165-4101(02)00044-7

Elliott, R.K., \& Jacobson, P.D. (1987). Audit technology: A heritage and a promise. Journal of Accountancy, 163(5), 198-205.

Gambatese, J.A., \& Hallowell, M. (2011). Enabling and measuring innovation in the construction industry. Construction Management and Economics, 29(6), 553-567. https://doi.org/10.1080/01446193.2011.570357

Hartono, J. (2012). Adoption of information technology on small businesses: The role of environment, organizational and leader determinant. International Journal of Business, Humanities, and Technology, 2(4), $60-66$. 
Hilgard, E.R., \& Bower, G.H. (1975). Theories of Learning. Englewood Cliffs, NJ: Prentice-Hall.

Ismail, N.A., \& Abidin, A.Z. (2009). Perception towards the importance and knowledge of information technology among auditors in Malaysia. Journal of Accounting and Taxation, 1(4), 61-69.

Janvrin, D., Bierstaker, J., \& Love, D. (2008). An examination of audit information technology use and perceived importance. Accounting Horizons, 22(1), 1-21. https://doi.org/10.2308/acch.2008.22.1.1

Lee, S. M., Kim, I., Rhee, S., \& Trimi, S. (2006). The role of exogenous factors in technology acceptance: The case of object-oriented technology. Information \& Management, 43(4), 469-480. https://doi.org/10.1016/j.im.2005.11.004

Manson, S., McCartney, S., Sherer, M., \& Wallace, W.A. (1998). Audit Automation in the UK and the US: A Comparative Study. International Journal of Auditing, 2(3), 233-246. https://doi.org/10.1111/1099-1123.00042

Porter, C.E., \& Donthu, N. (2006). Using the technology acceptance model to explain how attitudes determine Internet usage: The role of perceived access barriers and demographics. Journal of business research, 59(9), 999-1007. https://doi.org/10.1016/j.jbusres.2006.06.003

Shih, H. (2004). Extended technology acceptance model of Internet utilization behavior. Information \& Management, 41(6), 719-729. https://doi.org/10.1016/j.im.2003.08.009

Sundgren, S., \& Svanström, T. (2010). Auditor-In-Charge Characteristics and Going Concern Reporting Behavior: Does number of assignments, age and client fee dependence matter?. Contemporary Accounting Research, 31(2), 531-550. https://doi.org/10.1111/1911-3846.12035

Venkatesh, V., Morris, M., Davis, G., \& Davis, F. (2003). User acceptance of information technology: Toward a unified view. MIS quarterly, 27(3), 425-478. https://doi.org/10.2307/30036540

Young, R., \& Jordan, E. (2008). Top management support: Mantra or necessity?. International Journal of Project Management, 26(7), 713-725. https://doi.org/10.1016/j.ijproman.2008.06.001

\section{Copyrights}

Copyright for this article is retained by the author(s), with first publication rights granted to the journal.

This is an open-access article distributed under the terms and conditions of the Creative Commons Attribution license (http://creativecommons.org/licenses/by/4.0/). 